\title{
World Soybean Trade: Growth and Sustainability
}

\author{
Ian McFarlane', Ernesto A. O'Connor ${ }^{2}$ \\ ${ }^{1}$ School of Agriculture, Policy and Development, University of Reading, Reading, UK \\ ${ }^{2}$ Escuela de Economía Francisco Valsecchi, Facultad de Ciencias Económicas, Universidad Católica Argentina, \\ Buenos Aires, República Argentina \\ Email: eoconnor@uca.edu.ar, i.d.mcfarlane@reading.ac.uk
}

Received 20 March 2014; revised 18 April 2014; accepted 30 April 2014

Copyright (C) 2014 by authors and Scientific Research Publishing Inc.

This work is licensed under the Creative Commons Attribution International License (CC BY). http://creativecommons.org/licenses/by/4.0/

(c) () D

\section{Abstract}

Soybeans can be consumed directly as food, and in China they are the major ingredient in food products such as tofu and soy milk, but direct consumption is small relative to their wider use in animal feed, and it is the requirement for livestock feed that drives international trade. Rapid growth of economies and population, especially in Asia, has led to increased demand for animal protein and cooking oil. This paper analyses the recent growth in supply of soybeans from North and South America to China, and considers the factors that may affect this trade in future; a contrast is made with supply from North and South America to Europe, which has not been increasing. The constraints preventing an increase in supply of soybeans to Europe are reviewed. The paper concludes with brief discussion of the factors which will affect world markets for soybeans and soybean products in future.

\section{Keywords}

Soybeans, Feedstock, Land Use, Agricultural Economics, Commodity Trading, Sustainability

\section{Introduction}

The world oilseed trade consists of many closely substitutable commodities, with rape-, sunflower- and cottonseed as alternatives to soybeans. Divergent requirements for protein meal, vegetable oil and oil for biofuel determine the ratio of oilseeds to oilseed products that countries trade.

Trade and development are strictly connected; international trade has grown rapidly since modern economies were organized into industrial nations, and there has been a positive correlation between trade and development [1]. Nevertheless, globalization has not always improved development, considering social variables such as em- 
ployment or poverty [2].

It is important to consider also the ways in which patterns of trade in oilseeds affect the sustainability of food security in countries of origin and elsewhere [3], and the ways in which the patterns may adapt to climate change [4].

Imports of agricultural commodities into China from South American countries and also from the USA have grown rapidly since 2000. During the globalization of the 90s, trade between these countries and China had not developed so much; South American exporting countries had concentrated on trade expansion in the context of trade agreements such as FTAA, European Union, MERCOSUR, and a gradually increasing trade with the ASEAN. Intra-area trade and bilateral agreements were the main strategies.

Sharp growth in China's presence in world trade since the beginning of the new decade in the 2000s changed world trade trends for most of the MERCOSUR ${ }^{1}$ countries, and increased the exports of some commodities from USA. The traditional destinations for South American agriculture and food exports are mainly some countries of Europe and some intra-trade in the continent, and it was surprised by an increasing demand from China. International trade in soybeans has been especially important, since China's demand has been persistently strong. The importance of Chinese trade with LATAM has been studied during the last years as a source of growth and development [5] [6].

By contrast, soybeans exports from MERCOSUR and USA to European Union (EU) countries have not kept pace with the soybean boom. There has been a decline in production as a consequence of EU determination not to permit cultivation of the GM (transgenic) varieties of soybean which have been economically successful elsewhere [7]; there has also been a decline in imports associated with delayed approval of import of GM varieties authorized for cultivation in the countries of origin, and with a policy of zero tolerance of low level presence in import consignments of GM varieties not yet approved for import into EU [8]. The necessary protein content in animal feed in the EU is made up from a variety of sources.

The aim of this paper is to analyze the recent growing soybean Chinese trade on MERCOSUR economies and the soybean trade concentration situation, in contrast with the absence of soybean trade with the EU. The paper is organized as follows. Section 2 analyses the international context and China's influence with soybean imports since the 2000s. Section 3 focuses on soybean suppliers, and the South American agricultural boom, presenting soybean production and exports evolution to China by country. Section 4 studies some consequences of the agricultural boom in MERCOSUR, related to social, sustainability and trade strategy items. The EU policy on soybean markets is studied in Section 5 and Section 6 concludes.

\section{Soybean Suppliers: China's Influence and the Soybean Export Boom in the 2000s}

Since 2002 China's trade with Latin American economies has developed rapidly; in particular, in Chinese imports of raw materials and food. Chinese demand has been mainly for primary goods, such as grains and oilseeds, and also for part-processed agricultural items, such as meat, dairy, oils, selected fruit and vegetables, seafood and leather. Demand has also been high for fuel oil and metals, mainly from Brazil and Chile.

The impact of the trade between Latin America and China has varied among South American countries, and not all of them have won with stronger exports from the new paradigm. The possibility of export diversification, the introduction of increasing value added goods, and the adoption, or not, of long run bilateral trade strategies, have been the causes of some of the main differences between the relations established by these countries with China.

Long run trends indicate that Latin America has been the region in the world with the highest growth trade rates with China in the period 1990 to 2010. In the 2000s, trade with China has increased much more than the world's trade, and more than in any other region of the world [6]. The process increased during the first decade of this century, and in the period 2005-2009 growth rates of China-Latin America trade have doubled. The importance of China-Latin America trade has been proved during the 2009 world crisis: the contraction in exports occurred in all destinations except China; while in 2009 exports to the United States and the European Union fell by $26 \%$ and $28 \%$ respectively, those to Asia fell by only $6 \%$, but to China increased by $5 \%$. It is relevant that China's exports to United States have slowed in the last years 2005-09, showing the lowest growth rate of Chinese exports, to 10.2 annual percent.

These data confirm the growing importance China has acquired as export destination for this region. It is im-

${ }^{1}$ In this paper, the MERCOSUR countries considered are the soybean producers: Argentine, Brazil, Paraguay, Uruguay and Bolivia. 
portant to remember that Latin America total trade with China shows structural trend deficit, mainly due to the increasing negative balance of Mexico and Central America. In contrast, MERCOSUR economies showed quite balanced trade during the last ten years, which has been relevant to understand their recent high growth. The MERCOSUR countries have benefitted the most from the Chinese trade boom.

Food security has been the most dynamic priority for China as well as for other areas, and stimulated soybean chain exports in particular. MERCOSUR countries, with intensive production of food security goods, such as grains, oils, milk and dairy, meats fresh and meats processed, have all gained benefit, but the products most in demand have been the ones of the soybean chain, produced mostly by Brazil and Argentine, and then by Paraguay, Uruguay and Bolivia. Five South American countries registered a soybean production growth rate of $248 \%$ between 1995 and 2013, with a total production of 142 Mt, consolidating as the world's principal soybean production area, with a 55\% production market share. Of those five, Argentine has been, by far, the country with the largest production expansion, from $12 \mathrm{Mt}$ in 1995 to $49 \mathrm{Mt}$ in 2013, registering the highest rate growth between the main countries (Table 1). Brazil remains the main producer in the MERCOSUR region, and has now matched soybean output in the USA.

The world soybean sown area had reached 83 Mha in 2010, from 51.8 Mha in 2005, but in South America, the change went from 18.9 to 43 Mha during those years. In 2012 Argentina, Bolivia, Brazil, Paraguay and Uruguay harvested 50 Mha with soybean.

The production boom had different causes, and started in Argentina. The first favorable shock for the Argentine agriculture happened in 1991, when the new government eliminated the $41 \%$ tax rate on exports. The sown area started to expand, after a decade of decline (-5.7\% in the 80s). In 1997, zero tillage innovation practices spread in the pampas, enabled by introduction of genetically modified (GM) herbicide-tolerant varieties, and the sown area received new stimulus. In this decade, the sown area growth was $31.4 \%$, reaching 25 Mha. In the 2000s, two important factors modified the incentives to produce more agricultural goods. After the recession 1999-2001 and the Argentine devaluation of 2002, tradable goods prices were nearly 260\% higher (the exchange rate with US\$ went from $1=1$ to $1=3.6$ ), and the international commodities price boom started as China's demand grew exponentially. The international commodities prices boom, since 2002, was a second positive shock to agricultural relative prices, and sown area continued increasing in Argentina throughout the decade.

Public policies for the agricultural and livestock activity in Argentina changed over the last 20 years, in two phases: 1990-2001-liberalization of external trade, and 2002-2010 - export taxes and restrictions to export, with stronger state intervention from 2006. International commodities prices were also distinct: not so high in the 90s, and at record levels during the 2000s. Nevertheless, the reintroduction of the export taxes in April 2002,

\begin{tabular}{cccccc}
\hline \multicolumn{5}{c}{ Table 1. Soybeans: production by main countries $(1995-2013)$} & tonnes. \\
\hline & & & & Var\% & Market share \\
\hline & $1994 / 1995$ & $2007 / 2008$ & $2012 / 2013$ & $2013 / 2008$ & $2013, \%$ \\
\hline Argentina & $12,133,000$ & $46,238,087$ & $49,300,000$ & 6.6 & 19.0 \\
Bolivia & 870,074 & $1,259,676$ & $1,675,369$ & 33.0 & 0.6 \\
Brazil & $25,682,636$ & $59,242,480$ & $82,000,000$ & 38.4 & 31.7 \\
Paraguay & $2,212,109$ & $6,311,794$ & $8,300,000$ & 31.5 & 3.2 \\
Uruguay & 15,500 & 880,000 & 968,000 & 10.0 & 0.4 \\
South America & $\mathbf{4 0 , 9 1 3 , 3 1 9}$ & $\mathbf{1 1 3 , 9 3 2 , 0 3 7}$ & $\mathbf{1 4 2 , 2 4 3 , 3 6 9}$ & 24.8 & 54.9 \\
United States & $\mathbf{5 9 , 1 7 4 , 0 0 0}$ & $80,748,700$ & $82,560,000$ & 2.2 & 31.9 \\
China & $13,510,894$ & $15,545,141$ & $12,600,000$ & -18.9 & 4.9 \\
India & - & $9,100,000$ & $11,500,000$ & 26.4 & 4.4 \\
Other countries & - & $8,500,000$ & $10,000,000$ & 17.6 & 3.9 \\
Total & $\mathbf{1 1 3 , 5 9 8 , 2 1 3}$ & $\mathbf{2 2 7 , 8 2 5 , 8 7 8}$ & $\mathbf{2 5 8 , 9 0 3 , 3 6 9}$ & $\mathbf{1 3 . 6}$ & $\mathbf{1 0 0 . 0}$ \\
\hline
\end{tabular}

Sources: FAOSTAT, USDA. 
with rates of $13.5 \%$ for soybeans, was followed by a permanent increment in the rates, until in 2007 soybeans were taxed with a $35 \%$ rate, sunflower with a $32 \%$ rate, wheat with a $23 \%$ rate, and corn with a $20 \%$ rate. These are the present rates for grains exports at the time of writing (2014). Government subsidies to the agrifood industry increased from 2005, as a consequence of a food security policy, introducing new distortions to internal prices. The differential treatment between soybean (favourable) and other crops and livestock (unfavourable) from 2007 ended in a strong drop of the livestock and the corn and wheat production [9] [10].

\section{The Agricultural Boom in MERCOSUR}

Leading technology innovations have also been significant, notably the adoption of zero tillage (8\% of world production of grains, concentrated in Argentina and Brazil), associated with the introduction of GM varieties of herbicide-tolerant soybeans from 1997, and also the use of bio-inputs (inoculants), and precision agriculture using satellite data to calibrate seeding and fertilizer dosage. The result has been an expansion into new areas for grains cropping in MERCOSUR countries.

International trade of soybeans has been growing since the beginning of the 2000s. Table 2 shows the evolution of world soybean trade and the importance of Chinese soybeans demand. The USA remained as the largest single supplier of Chinese soybean in 2012, but taken together, countries of the MERCOSUR region provided a larger quantity, $55 \%$ of total Chinese soybean imports. World soybean trade is dominated by China, which absorbs $60.9 \%$ of total world trade of soybean.

Soybean oil crushing industry has also developed in Argentine, with US\$ 4.9 million traded in 2011, the highest value at the time of writing, and Argentina is a main producer and exporter. In 2013, Argentina produced 30.4 Mt of soybean meal, increased from only 1 Mt in 1981 [11]. Many economic factors affect the profitability of crushing operations; for example, competition in the freely traded world market for refined vegetable oils put pressure on the gross margin available from oil crushing in 2013 [12].

Soybean trade has become concentrated. In Argentine, for example, $78.7 \%$ of soybeans exports are concentrated in China, and 30\% of Argentine soybean oil is sold to China. Soybean pellets for animal feed are not a significant export to China, since the EU, India and ASEAN countries are the principal source of demand. Brazil's agricultural exports show similar path dependence: $66.5 \%$ of soybean and $34 \%$ of soybean oil are exported to China. Uruguay is another country with high export with China: $89 \%$ of soybeans.

From China's point of view, the soybean chain is the most critical import agrifood chain: $71.5 \%$ of soybean oils come from Argentina and Brazil, and 52\% of soybeans from those countries plus Uruguay and Paraguay (averages 2008-2012). South American agricultural commodity producers saw China as a new market, absorbing increasing volumes as world commodity prices rose during the 2000s, and presenting a stable and profitable market.

\begin{tabular}{|c|c|c|c|c|c|}
\hline & & & & & Var\% \\
\hline & 2004 & 2008 & 2011 & 2012 & $2012 / 2004$ \\
\hline Argentina & $1,178,821$ & $3,609,035$ & $4,388,957$ & $4,748,121$ & 302.8 \\
\hline Brazil & $1,621,736$ & $5,324,052$ & $10,957,102$ & $11,379,451$ & 601.7 \\
\hline Bolivia & 25,460 & 17,255 & 19,969 & 45,789 & 79.8 \\
\hline Paraguay & 457,874 & 985,741 & $2,294,438$ & $2,523,882$ & 451.2 \\
\hline Uruguay & 121,487 & 154,789 & 372,298 & 395,874 & 225.9 \\
\hline Mercosur & $3,405,378$ & $10,090,872$ & $18,032,764$ & $19,093,117$ & 460.7 \\
\hline United States & $2,328,762$ & $7,301,040$ & $10,452,148$ & $14,973,152$ & 543.0 \\
\hline Other & - & - & $1,241,154$ & 910,314 & - \\
\hline China imports from world & $6,979,167$ & $21,815,275$ & $29,726,066$ & $34,976,583$ & 401.2 \\
\hline Total world trade & $19,703,420$ & $44,159,744$ & $51,944,398$ & $57,383,248$ & 191.2 \\
\hline
\end{tabular}

Sources: ITC, INDEC, IBGE, USDA. 
Future elasticity of supply in the producer countries is the key. So the export performance question for the future would seem to turn on further developments in biotechnology to ensure South American supply to satisfy demand from China for the next years [13].

\section{Consideration of Sustainability and of Trade Strategy for MERCOSUR}

Revealed comparative advantage (RCA) as formulated by [14] evolved from the historic two-country concept of comparative advantage, to broaden analysis to cover multiple participants. These exists a comparative advantage if the RCA Index is greater than one. The RCA Index is applied here to Argentina and Brazil soybean total exports (Table 3).

The RCA Index series for Argentina and for Brazil emphasizes the Chinese dependence. In general, Argentina presents higher rates for soybean trade with China than Brazil, but a decreasing trend, that reflects a persistent loss of competitiveness since 2005 to 2013. Brazil has a more uniform and trend-free series.

For soybean oil trade, where Argentina is a leader country, the same decreasing trend is observed. In summary, although Argentina's soybean trade with China is growing, Argentina's comparative advantage may not be sustainable indefinitely. A decrease in Argentina's total exports since 2011, plus another decrease in soybean exports due to negative climate impacts and less rural investment associated with more interventional public policies may be part of the problem. In contrast, Brazil`s soybean exports have continued growing since 2011, though total exports have stabilized.

The agricultural and soybean boom registered in the MERCOSUR countries around the soybean boom has had lots of positive impacts on economic growth, trade improvement, wealth creation, fiscal tax contribution to different government levels, employment generation and regional development.

For Argentina, the impact of the expansion of soybean planting area has been largely positive, increasing businesses such as local retail, cars sales and real estate. But soybean is also an example of physical as well as business expansion and production system transformation, with risks related to growth dependency, and with some negative environment impacts. There are immediate problems with monoculture, if crop rotation with

Table 3. Revealed comparative advantage for Argentina and Brazil’s soybean.

\begin{tabular}{|c|c|c|c|c|c|c|c|}
\hline & 2005 & 2006 & 2009 & 2010 & 2011 & 2012 & 2013est \\
\hline \multicolumn{8}{|l|}{ Argentina } \\
\hline Soybean exports & 2373 & 4683 & 1654 & 6001 & 5335 & 3158 & 4432 \\
\hline Soybean oil exports & 2120 & 4895 & 3135 & 4015 & 4926 & 4204 & 4376 \\
\hline Total exports & 40,013 & 70,020 & 65,668 & 68,500 & 84,289 & 80,927 & 83,028 \\
\hline World soybean trade & 19,065 & 44,160 & 36,344 & 44,359 & 51,944 & 57,383 & 61,548 \\
\hline World soybean oil trade & 5,183 & 12,578 & 7,760 & 9,745 & 12,931 & 11,603 & 12,445 \\
\hline World trade & $10,159,000$ & $15,787,000$ & $12,204,000$ & $14,851,000$ & $18,200,000$ & $18,323,000$ & $18,927,659$ \\
\hline RCA index soybean & 32 & 23 & 10 & 24 & 22 & 12 & 15 \\
\hline \multirow[t]{2}{*}{ RCA index soybean oil } & 104 & 88 & 89 & 88 & 82 & 82 & 80 \\
\hline & 2005 & 2006 & 2009 & 2010 & 2011 & 2012est & 2013est \\
\hline \multicolumn{8}{|l|}{ Brazil } \\
\hline Soybean exports & 6341 & 10,844 & 11,413 & 11,036 & 16,312 & 17,246 & 17,961 \\
\hline Total exports & 118,529 & 197,942 & 182,995 & 201,815 & 256,040 & 242,578 & 242,179 \\
\hline World soybean trade & 19,065 & 44,160 & 36,344 & 44,359 & 51,944 & 57,383 & 61,548 \\
\hline World trade & $10,159,000$ & $15,787,000$ & $12,204,000$ & $14,851,000$ & $18,200,000$ & $18,323,000$ & $18,927,659$ \\
\hline RCA index soybean & 24 & 20 & 25 & 18 & 22 & 23 & 23 \\
\hline
\end{tabular}

Sources: WTO, FAOSTAT, ITC, NDEC,SECEX, Exports and trade in US\$’000. 
wheat and maize is inadequate, and other consequential concerns. Figuerola et al. [15] pointed out that the rise in the world demand for food poses a challenge to sustainability of soil fertility; the advantages of no-till agriculture are jeopardized when its use is linked to the expansion of crop monoculture. From other aspects, soybean expansion has had effects on land concentration and small farmers, rural development, and ultimately on migration and urban poverty. These changes embrace structural, institutional, agro-industrial, environmental and social aspects.

Another point is related to social changes motivated by the agricultural boom. Changes in land tenure have been partly caused by small producers who have seen no alternative to selling their land. This has intensified rural-urban migration in Argentina, Brazil and Paraguay. During the last three decades there has been a concentration process in the farming sector all over the world. The process involved changes in the number and in the size of the farm units, with a strong drop in the number of farms.

In Brazil, the national transport infrastructure restricts further increase in soybean trade. The distance from important soybean production regions, such as Matto Grosso, and the international ports is about 1.500 kilometers. Trucking over this distance imposes high transport costs [16]. Deforestation has advanced in some areas of Argentine, Brazil and Paraguay, opening questions about water sustainability and the sustainability of entire agricultural production. The Niña's drought phenomenon has been related to deforestation. Land availability will not be a major constraint on expected soybean expansion in South American countries, but the main point is the impact of increased soybean seeded area on the dynamics of land use, in particular on deforestation and unsustainable use of ecologically fragile land.

\section{EU View of Soybean Markets}

The EU is self-sufficient in vegetable oil production, but its protein deficit still makes it the world's largest importer of soybean meal and second-largest importer of soybeans. EU demand for soybeans persistently exceeds EU production: 1.4 Mt were produced in 2000 and only $0.9 \mathrm{Mt}$ in 2013 [17] whereas imports were $14.5 \mathrm{Mt}$ in 2000 and only 12.1 Mt in 2011 [18]; there were also $22 \mathrm{Mt}$ of soymeal [19]. Imports of soybeans, meal and oil by country of origin are shown in Table 4, where it can be seen that whereas in 2008 Brazil supplied almost $60 \%$ of soybeans imported into EU and almost half the soybean oil, by 2012 the proportion of soybeans and soybean oil from Brazil had decreased to about $46 \%$ and $10 \%$, although the proportion of soybean cake increased. The import of soybeans from USA also decreased significantly. These changes reflect the steadily increasing adoption of GM soybean varieties in North and South America, and continuing reluctance of European consumers to buy food labelled as containing GM ingredients. The increase of import of soybean cake from Brazil between 2008 and 2012 is consistent with the absence of any requirement in EU to label meat from GM-fed livestock as "GM".

European livestock farmers rely heavily on soybeans imports for animal feed. Europe imports most of the soybeans it uses; a large part of the world's animal feed supply, of maize as well as soybean, is GM, and the premium payable for being selective about GM traits or for requiring non-GM product (if available) puts EU livestock producers at a significant disadvantage. In addition to soybean and soybean meal, $2.5 \mathrm{Mt}$ of feed maize, $2 \mathrm{Mt}$ of oilseed rape are imported annually by the EU as animal feed [19].

EU opportunities for production of soybean are restricted by climate-most of Europe is too cold for successful cultivation. For those areas of Europe where cultivation is possible, it remains uneconomic while growers are denied access to GM varieties. Europe produces about $1 \mathrm{Mt}$ annually, against a total demand of the order of 30 to $40 \mathrm{Mt}$ (for animal feed there are some alternative but less economic sources of protein). Recent levels of production are illustrated in Figure 1 [17]. Note that production increased in Romania in the period 2002-2007, but then fell sharply. This was because cessation of cultivation of GM soybeans was made a condition of admission of Romania to the EU.

During the period 1960-1975, EU imports of soybeans increased due to rapid growth in livestock production and duty-free concessions signed in trade agreements. In the 1970s and 1980s, soybean consumption slowed as EU agricultural policies subsidized a large expansion in domestically produced rapeseed and sunflower seed, eroding the market for oilseed imports. The USA challenged these subsidies and, in 1992, the EU committed to a number of reforms, including reduced per-hectare direct payments to oilseed producers. The reforms encouraged EU farmers to scale back oilseeds planting. However, recent EU biodiesel policies have partly reversed the trend [20]. 
Table 4. EU soybean, soybean oil and soybean cake imports, 2008 and 2012 Mt.

\begin{tabular}{|c|c|c|c|c|c|c|}
\hline & \multicolumn{3}{|c|}{2008} & \multicolumn{3}{|c|}{2012} \\
\hline & Soybeans & Soybean oil & Soybean cake & Soybeans & Soybean oil & Soybean cake \\
\hline Argentina & 0.28 & 0.44 & 0.80 & 0.03 & 0.02 & 0.45 \\
\hline Brazil & 8.51 & 0.51 & 9.06 & 5.55 & 0.04 & 9.26 \\
\hline Paraguay & 0.89 & 0.00 & 0.01 & 1.66 & 0.01 & 0.17 \\
\hline Uruguay & 0.19 & - & 0.01 & 0.31 & - & - \\
\hline United States & 3.66 & 0.00 & 0.48 & 2.13 & - & 0.74 \\
\hline Other countries & 0.89 & 0.15 & 12.50 & 2.31 & 0.30 & 8.86 \\
\hline \multirow[t]{2}{*}{ Total } & 14.4 & 1.1 & 22.9 & 12.0 & 0.4 & 19.5 \\
\hline & \multicolumn{6}{|c|}{$\%$ of total: } \\
\hline Argentina & 1.9 & 39.9 & 3.5 & 0.3 & 6.6 & 2.3 \\
\hline Brazil & 59.0 & 46.6 & 39.6 & 46.3 & 9.8 & 47.5 \\
\hline Paraguay & 6.2 & 0.2 & 0.0 & 13.9 & 2.7 & 0.9 \\
\hline Uruguay & 1.3 & - & 0.0 & 2.6 & - & - \\
\hline United States & 25.4 & 0.2 & 2.1 & 17.7 & - & 3.8 \\
\hline Other countries & 6.1 & 13.2 & 54.7 & 19.2 & 80.9 & 45.5 \\
\hline
\end{tabular}

Source: UN commodity trade statistics.



Figure 1. Soybean production in EU.

Gryson et al. [21] noted that EU regulations have allowed the placing on the European market some GM products in food and feed chains, and have defined their rules of traceability and labelling. For some supply chains, such as for derived products that are used in the production of feed, there are no labelling requirements 
for animal products derived from animals fed with genetically modified organisms (GMOs) [22]. This ruling has partially eased the constraints on sourcing the protein required for animal feed.

\section{Conclusions}

The soybean crop is one of the most important crops worldwide. The crop is grown on an estimated $6 \%$ of the world's arable land, and since the 1970s, the area in soybean production has the highest rate of increase of any major crop. Hartman et al. [23] noted a number of important abiotic and biotic constraints that threaten soybean production by directly reducing seed yields and/or seed quality. Abiotic constraints include extremes in nutrients, temperatures and moisture. These may reduce production directly, but also indirectly through increases in pathogens and pests. Biotic constraints tend to be geographically and environmentally restricted. Adequate management strategies, such as the use of varieties resistant to disease, are not as yet available, but there is strong investment in technologies to improve crop characteristics; new genomic technologies, in particular, offer the potential to improve dietary quality for people throughout the world.

New varieties of soybean will allow farmers to raise soybeans where soil conditions were considered unsuitable, enabling growers to produce soybeans in formerly uncultivated regions of Argentina and Brazil. Overall, there are likely to be increases in both soybean yields and harvested acreage, and associated substantial increases in soybean meal and oil production.

In Europe, the constraints imposed by agricultural policy development, coupled with widespread antipathy to GM technology, have held back any expansion in soybean trading. European agricultural policy reforms have already removed some of the anomalies in world sugar trading, and in due course the restrictions affecting soybean imports may be relaxed. Crop biotechnology is continually evolving, and may soon remove distinctions between methods used to develop new crop varieties [24]. Thus Europe may join China and Asian countries in providing further expansion of the world market for soybeans.

It seems certain that international soybean trade will continue to expand.

\section{References}

[1] Helpman, E. (2010) The Mystery of Economic Growth. Harvard University Press, Cambridge.

[2] Helpman, E., Itskhoki, O. and Redding, S. (2010) Inequality and Unemployment in a Global Economy. Econometrica, 78, 1239-1283. http://dx.doi.org/10.3982/ECTA8640

[3] Mittal, A. (2009) The 2008 Food Price Crisis: Rethinking Food Security Policies. UN.G-24 Discussion Paper No. 56.

[4] Schmidhuber, J. and Tubiello, F.N. (2007) Global Food Security under Climate Change. Proceedings of the National Academy of Sciences, 104, 19703-19708. http://dx.doi.org/10.1073/pnas.0701976104

[5] IADB (2010) Institute for the Integration of Latin America and the Caribbean. Nuevas tendencias en las políticas comerciales y productivas de la República Popular China. Carta Mensual INTAL 166, Junio.

[6] ECLAC (2010) La República Popular de China y América Latina y el Caribe: Hacia una relación estratégica. Santiago, Chile, Abril.

[7] Devos, Y., Demont, M., Dillen, K., Reheul, D., Kaiser, M. and Sanvido, O. (2009) Coexistence of Genetically Modified (GM) and Non-GM Crops in the European Union. A Review. Agronomy for Sustainable Development, 29, 11-30. http://dx.doi.org/10.1051/agro:2008051

[8] McFarlane, I., Park, J., Ceddia, G. and Phipps, R. (2011) Transgenic Soya Beans: Economic Implications for EU Livestock Sector. Quality Assurance and Safety of Crops \& Foods, 3, 54-62. http://dx.doi.org/10.1111/j.1757-837X.2011.00096.x

[9] Nogués, J.J. (2011) Agricultural Export Barriers and Domestic Prices. Argentina during the Last Decade. FAO, June 2011.

[10] Bolsa de Cereales (2011) Desarrollo productivo y cambio de paradigma. Diez años de agroindustria argentina. 20002010. Instituto de Estudios Económicos. Bolsa de Cereales, Buenos Aires, Junio.

[11] Index Mundi (2014) Argentina Soybean Meal—Production by Year. www.indexmundi.com/agriculture/?country=ar\&commodity=soybean-meal\&graph=production

[12] Rabo Bank (2013) Outlook 2014—Recovery on a Shaky Footing. Rabo Bank Economic Research Department.

[13] O’Connor, E. (2013) China, Brazil and Argentina: Agricultural Trade and Development? American Journal of Chinese Studies, 20, 101-112.

[14] Balassa, B. (1965) Trade Liberalisation and "Revealed” Comparative Advantage. The Manchester School, 33, 99-123. 
http://dx.doi.org/10.1111/j.1467-9957.1965.tb00050.x

[15] Figuerola, E.L.M., Guerrero, L.D., Rosa, S.M., Simonetti, L., Duval, M.E., et al. (2012) Bacterial Indicator of Agricultural Management for Soil under No-Till Crop Production. PLoS ONE, 7, Article ID: e51075. http://dx.doi.org/10.1371/journal.pone.0051075

[16] Lazzaroto, J. and Hirakuri, M.H. (2009) Evolucao e Perspectivas de DesempenhoEconomico asociadas com a Producao de Soja nos Contextos Mundial e Brasileiro. Documentos 319. EMBRAPA-SOJA. Ministerio da Agricultura, Pecuaria e Abastecimento. Londrina PR, Brasil, Dezembro.

[17] EuroSTAT (2014) European Agricultural Production. http://epp.eurostat.ec.europa.eu

[18] FAOSTAT (2014) Crops and Livestock Products. http://faostat3.fao.org

[19] EuropaBio (2014) Why Does the EU Import GM Crops? http://www.europabio.org/why-does-eu-import-gm-crops

[20] USDA (2014) Soybeans \& Oil Crops. www.ers.usda.gov/topics/crops/soybeans-oil-crops/trade.aspx\#foreign

[21] Gryson, N., Eeckhout, M., Trouillier, A., Le Bail, M. and Soler, L.-G. (2009) Strategies for Coexistence of GM and Non-GM Soy from Import to Feed Processing. Environmental Biosafety Research, 8, 153-159. http://dx.doi.org/10.1051/ebr/2009008

[22] GMO-Compass (2007) GMO Labelling of Foodstuffs Produced from Animals-The Discussion Continues. www.gmo-compass.org/eng/news/stories/286.gmo_labelling_animal_products_discussion_continues.html

[23] Hartman, G., West, E. and Herman, T. (2011) Crops That Feed the World 2. Soybean-Worldwide Production, Use, and Constraints Caused by Pathogens and Pests. Food Security, 3, 5-17. http://dx.doi.org/10.1007/s12571-010-0108-x

[24] Lusser, M., Parisi, C., Plan, D. and Rodríguez-Cerezo, E. (2011) New Plant Breeding Techniques: State-of-the-Art and Prospects for Commercial Development. Publications Office of the European Union. 